\title{
Carbon-starvation induction of the ugp operon, encoding the binding protein-dependent sn-glycerol-3-phosphate transport system in Escherichia coli
}

\author{
Ti-Zhi Su ${ }^{1}$, Herbert P. Schweizer ${ }^{2}$, and Dale L. Oxender ${ }^{1}$ \\ ${ }^{1}$ Department of Biological Chemistry, University of Michigan, Ann Arbor, MI 48109-0606, USA \\ ${ }^{2}$ Department of Microbiology and Infectious Diseases, University of Calgary, Calgary, Alberta (Canada) T2N 4N1
}

Received March 15, 1991

\begin{abstract}
Summary. The gene products of the $u g p$ operon of Escherichia coli are responsible for the uptake of $s n$ glycerol-3-phosphate and certain glycerophosphodiesters. The regulation of $u g p$ is mainly phoBR-dependent. Significant expression, however, can be observed even in the presence of high concentrations of phosphate, a condition which normally completely represses pho expression. Pho-independent ugp expression was found to be derepressed during the late logarithmic growth phase due to carbon starvation. Among different carbon sources tested, glucose caused the most complete repression. Addition of cAMP prevented glucose repression, indicating that a cAMP-CRP control mechanism may be directly or indirectly involved in the carbon-starvation response. This conclusion is supported by the fact that pho-independent ugp expression correlated with the presence of the cya and $c r p$ gene products.
\end{abstract}

Key words: $u g p$ operon, gene regulation - Regulation

Escherichia coli possesses two transport systems for $s n^{-}$ glycerol-3-phosphate (G3P). The genes involved in the $g l p T$-dependent transport system are part of the $g l p$ regulon, which includes the sequences coding for the enzymes required for utilization of glycerol and its derivatives as carbon and energy sources (Lin 1976; Ludtke et al. 1982). The second G3P transport system, which is also responsible for the transport and concomitant hydrolysis of glycerophosphodiesters (Brzoska and Boos 1988), is encoded by the $u g p$ operon (Argast et al. 1987). This operon consists of at least five genes, $u g p B, A, E, C$, and $Q$, organized as a single transcription unit (Overduin et al. 1988). Genetic analyses have shown that ugp expression is co-regulated with other members of the pho regulon (Argast and Boos 1980; Schweizer and Boos 1985), especially phoA, the structural gene for alkaline

Offprint requests to: D.L. Oxender phosphatase. However, a more detailed analysis revealed significant differences. Whereas phoA expression is completely repressed in the presence of excess phosphate $\left(\mathrm{P}_{\mathrm{i}}\right)$ $(0.64 \mathrm{mM}), u g p$ expression is not completely repressed under such conditions (Schweizer and Boos 1984; Wanner and McSharry 1982). Wanner and McSharry (1982) demonstrated that the expression of a $u g p-l a c Z$ fusion gene in vivo was affected by, among other factors, carbon starvation. These results indicated that the pho-dependent regulation may not be the only regulatory mechanism that controls expression of the Ugp system. During our attempt to construct a phosphate-regulated expression system we found that a significant amount of $\mathrm{P}_{\text {ugp }}$-directed expression of target genes could only be repressed in the presence of high concentrations of glucose, supporting the hypothesis of multiple controls of ugp expression (Su et al. 1990). Recently, Kasahara et al. (1991) also showed that the dual regulation occurs at two interspaced promoters. In the present study, additional physiological and genetic evidence is presented which supports the notion of dual regulation of $u g p$ expression by phosphate- and carbon-starvation.

For these studies, a $174 \mathrm{bp}$ EcoRI-Hinf $\mathrm{I}$ fragment containing the $u g p$ promoter region was isolated and cloned between two transcription terminators, resulting in the $\mathrm{P}_{u g p}$-based expression vector $\mathrm{pPH} 3$ ( $\mathrm{Su}$ et al. 1990). Two reporter genes, lac $Z$ (encoding $\beta$-galactosidase or LacZ) and $x y l E$ (encoding catechol 2,3-dioxygenase or XylE) (Inouye et al. 1981 a), were inserted into this vector, forming plasmids $\mathrm{pPZ3}$ and $\mathrm{pPX} 3$, respectively (Su et al. 1990). In these plasmids, expression from the ugp promoter can be easily monitored by measuring the respective enzyme activities.

When ugp-promoted XylE and LacZ expression was examined in a wild-type strain and several pho regulatory mutants grown under conditions of excess (TGE) and limiting (TGL) $\mathrm{P}_{\mathrm{i}}$, ugp expression from the plasmid paralleled chromosomally-derived phoA expression. As shown in Table 1, approximately $20 \%$ of the total $\beta$ galactosidase activity expressed from $\mathrm{P}_{\text {ugp }}$ was not $\mathrm{P}_{\mathrm{i}}$ repressible [depending on the experiment, period of pre- 
Table 1. Alkaline phosphatase and $\mathrm{P}_{u g p}$-directed $\beta$-galactosidase activities in wild-type and pho regulatory mutants ${ }^{\mathrm{a}}$

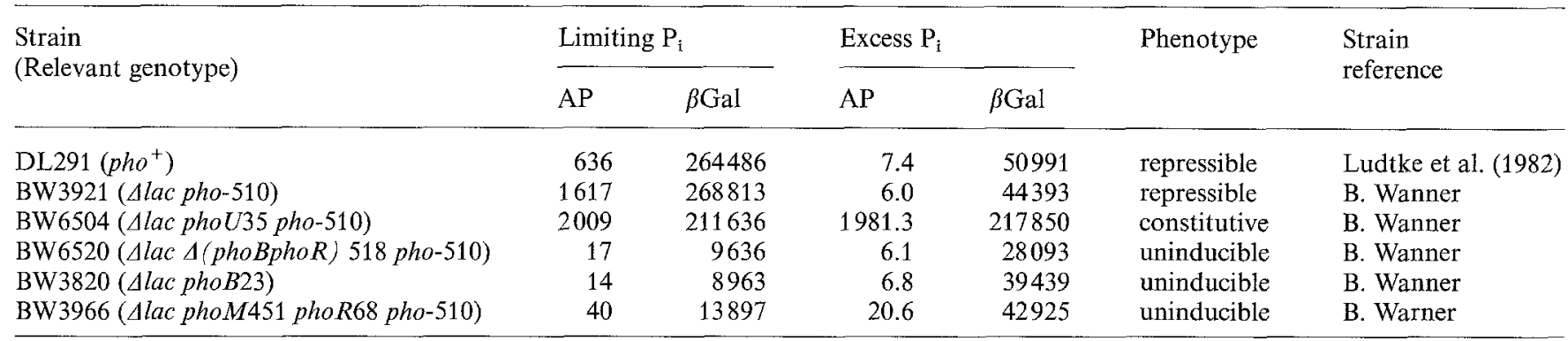

${ }^{\text {a }}$ Strains harboring plasmid $\mathrm{pPZ} 3\left[\Phi\left(\mathrm{P}_{\text {ugp }}\right.\right.$-lac $\left.\left.Z\right)\right]$ were grown into mid- to late-logarithmic phase in TGE medium [TG (Echols et al. 1961) containing $10 \mathrm{mM} \mathrm{KH}{ }_{2} \mathrm{PO}_{4}, \mathrm{P}_{\mathrm{i}}$ ] supplemented with $0.2 \%$ glucose. They were harvested, washed twice with $\mathrm{P}_{\mathrm{i}}$-free and glucose-free TG medium, and then inoculated into TGE $(10 \mathrm{mM} \mathrm{P}$ excess $\left.\mathrm{P}_{\mathrm{i}}\right)$ or TGL $\left(0.064 \mathrm{mM} \mathrm{P}_{\mathrm{i}}\right.$, limiting $\left.\mathrm{P}_{1}\right)$ medium with $0.2 \%$ glucose. Where necessary, the TG medium was supplemented with thiamine $(5 \mu \mathrm{g} / \mathrm{ml})$ and ampicillin $(50 \mu \mathrm{g} / \mathrm{ml})$. For enzyme assays, aliquots were removed from the cultures about $6 \mathrm{~h}$ after entering stationary phase growth and immediately placed on ice. Chloramphenicol was added to $100 \mu \mathrm{g} / \mathrm{ml}$. The ice-cold cells $(0.5 \mathrm{ml})$ were pelleted, washed once with $0.1 \mathrm{M}$ TRIS-HCl (pH 8.0), and resuspended in the same buffer. The cells were then permeabilized by adding $20 \mu \mathrm{l}$ of chloroform and $10 \mu 1$ of $0.1 \%$ sodium dodecyl sulfate. $\beta$-galactosidase and alkaline phosphatase were analyzed as previously described (Brickman and Beckwith 1975; Miller 1972). The molar extinction coefficients used for calculation of specific activities are $\varepsilon_{410}=1.62 \times 10^{4}$ (alkaline phosphatase) and $\varepsilon_{420}=4.5 \times 10^{3}$ ( $\beta$-galactosidase). Specific activities are expressed in nmol of products liberated per minute per $\mathrm{mg}$ protein

$\mathrm{P}_{\mathrm{i}}$, phosphate; AP, Alkaline phosphatase; $\beta$-Gal, $\beta$-galactosidase
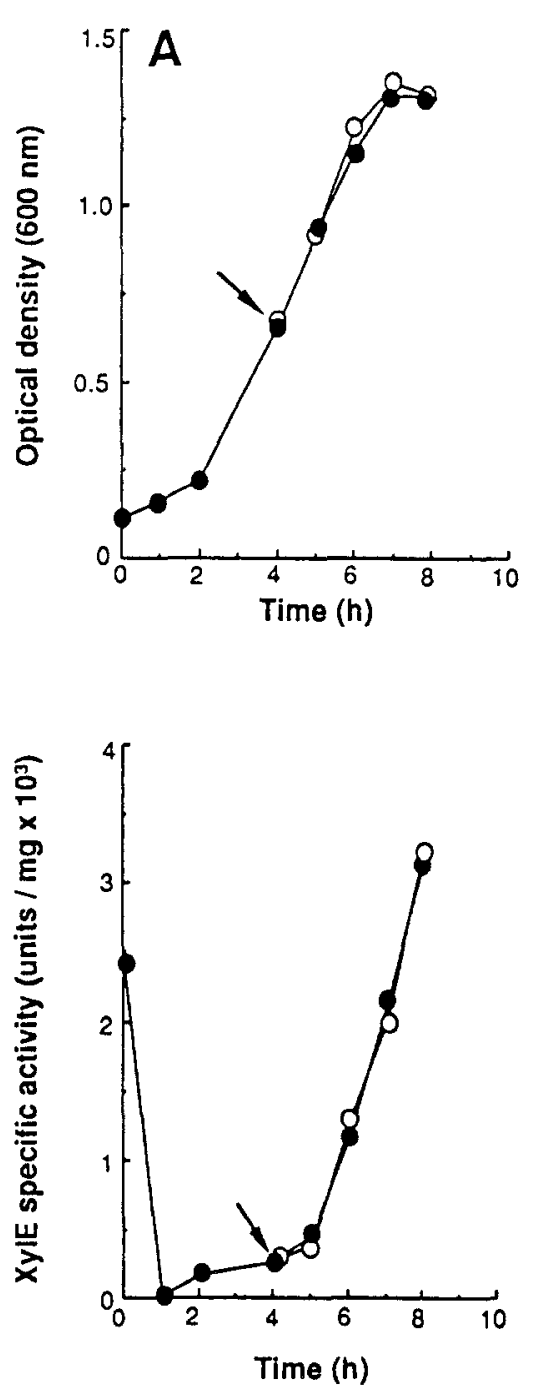
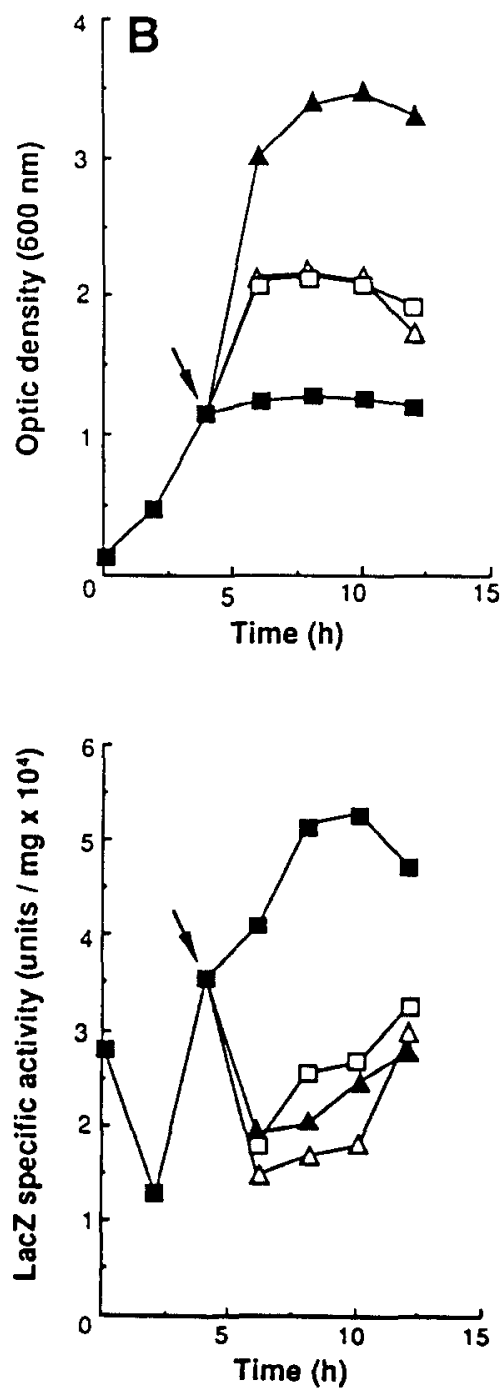

Fig. 1 A, B. The pho-independent repression and derepression of $\mathrm{P}_{u g p}$-directed catechol 2,3-dioxy* genase and $\beta$-galactosidase synthesis. Strain DL219 harboring plasmid pPX3 (panel A) or pPZ3 (panel B) was grown in TGE medium and then inoculated into prewarmed TGE medium as described in Table 1. Samples were withdrawn at the indicated intervals and assayed for optical density (upper panels) and $\mathrm{XylE}$ activity (lower panel A) and LacZ activity (lower panel B) as described in Tables 1 and 3 . At the time indicated by the arrow, each culture was divided. Additional $\mathrm{P}_{\mathrm{i}}(10 \mathrm{mM}$; pane$1 \mathrm{~A}$, open circles), glucose $(0.2 \%$; panel $\mathrm{B}$, open triangles) or TYE (Miller 1972; panel B, closed triangles) was added. Alternatively, the cells were harvested by centrifugation and resuspended in prewarmed fresh TGE medium (panel $\mathrm{B}$, open squares). As a control, cultures were grown without additions or medium changes (panel A, closed circles; panel B, closed squares) 
growth prior to the assay, and the indicator gene analyzed, this value varied between $5 \%$ and $20 \%$ (cf. Table 3, line 1)]. Similar levels of expression were also observed when $\mathrm{P}_{\mathrm{i}}$-uninducible mutants (BW6520, BW3820 and BW3966) were grown in excess $\mathrm{P}_{\mathrm{i}}$. Furthermore, addition of excess $P_{i}(10 \mathrm{mM})$ to the already derepressed culture had no effect on further induction (Fig. 1A). These results demonstrate that the observed levels of $u g p$ expression were $p h o$-independent under conditions of excess $\mathrm{P}_{\mathrm{i}}$.

Since pPH3 is a high copy-number plasmid and the strains employed in this study possess only single copies of the pho regulatory genes, one explanation could be that these results are due to a copy number effect as originally claimed by Schweizer and Boos (1984). However, Inouye et al. (1981 b) have shown that the regulatory proteins produced by the haploid chromosomal regulatory genes are sufficient to cause complete repression and derepression of multiple copies of phoA. Thus, it is very unlikely that the high gene dosage of the $\mathrm{P}_{\text {ugp }}$ fusion genes could account for the pho-independent expression. This conclusion is further supported by the following observations (data not shown): 1) the basal levels of $u g p$ expression in excess $\mathrm{P}_{\mathrm{i}}$ were not repressed when the $p h o B R$ genes were present on a compatible multicopy plasmid; 2) the copy number of the $\mathrm{P}_{u g p}$-lac $Z$ or $\mathrm{P}_{\text {ugp }}-x y l E$ plasmid constructs did not significantly change during derepression, as assessed by determinations of $\beta$-lactamase specific activites; 3 ) when the ugp promoter region of the $\mathrm{P}_{u g p}$-driven $\operatorname{lac} Z$ gene was replaced by the tac promoter $\left(\mathrm{P}_{t a c}\right)$, uninduced $\beta$-galactosidase activity (excess $P_{i}$ in the absence of IPTG) expressed from $\mathrm{P}_{\text {ugp }}$ was 6-7 times higher than that expressed from the $\mathrm{P}_{\text {tac }}$, although the intrinsic strength of $\mathrm{P}_{\text {ugp }}$ is only about $80 \%$ of that of $\mathrm{P}_{t a c}$ promoter ( $\mathrm{Su}$ et al. 1990). The latter result also rules out the possibility that the observed levels of enzyme synthesis were due to transcriptional readthrough from a promoter within the vector.

To assess whether the observed pho-independent $u g p$ expression was due to carbon-starvation, growth-dependent levels of $u g p$-directed XylE or LacZ synthesis were determined (Fig. 1). Upon dilution of a derepressed culture into fresh TGE medium, a significant decrease in $u g p$-directed enzyme synthesis was observed (Fig. 1A, lower panel). During late exponential growth, a significant derepression of enzyme expression was observed. Addition of excess $P_{i}(10 \mathrm{mM})$ had no effect on derepression, showing that it was pho-independent (Fig. 1A, lower panel). Switching to fresh TGE medium, addition of TYE (Miller 1972), or addition of $0.2 \%$ glucose to the depleted growth medium during late exponential growth of the cells resulted in immediate resumption of growth, and a concomitant decrease in $u g p$-promoted LacZ synthesis (Fig. 1B). When the cells were cultured until they reached the stationary growth phase, the specific activity of LacZ increased again (Fig. 1B, lower panel). Fig. $1 \mathrm{~B}$ also displays a lack of TYE-specific induction, which was previously reported from the in vivo lac $Z$ fusion studies (Wanner and McSharry 1982). Since carbon source addition exerted the same effect as did different growth media, it can be concluded that carbonstarvation is closely correlated with the pho-independent expression. The effects of different carbon sources on pho-independent ugp expression were further examined by carrying out experiments analogous to those described above. When the kinetics of ugp derepression were examined, pho-independent expression was repressed by all three carbon sources tested (glycerol, glucose and succinate) during log phase growth, and derepressed in late $\log$ to early stationary growth phase (Fig. 2). We observed that only glucose exerted a concentration-dependent complete repression. In the presence of high concentrations of glucose (1-2\%), pho-independent $u g p$ expression was essentially completely repressed. Addition of cAMP relieved this repression (Table 2). The
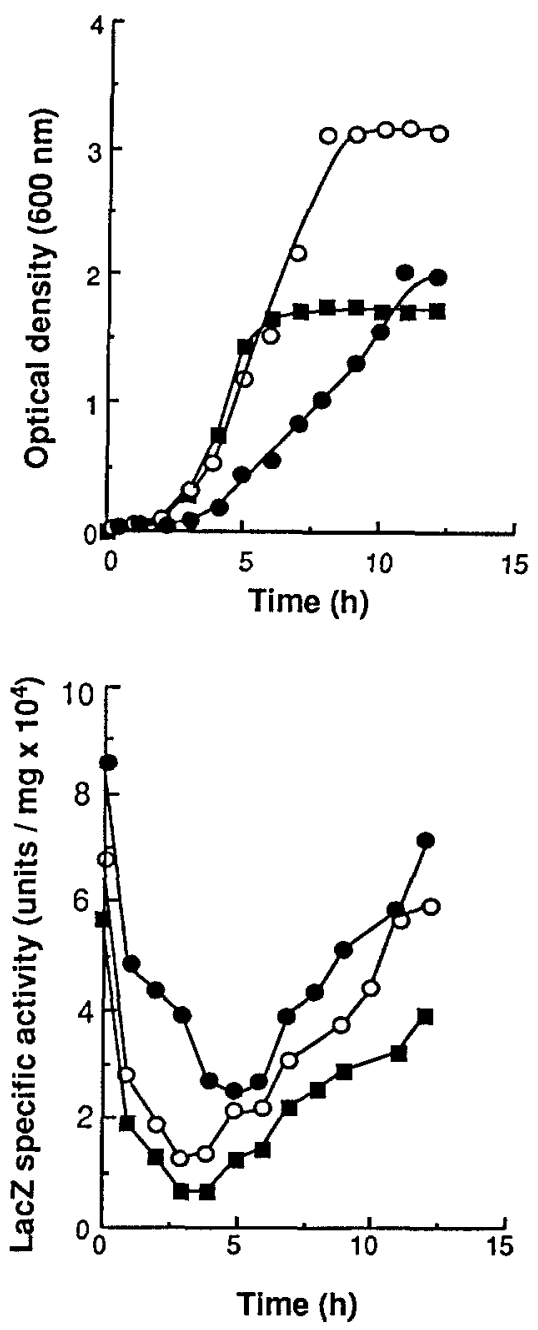

Fig. 2. Effect of carbon starvation on $\mathrm{P}_{u g p}$-directed $\beta$-galactosidase expression. Strain DL291/pPZ3 was pregrown in TGE medium (glucose, closed squares) or in TE medium in which glucose was replaced by the indicated carbon sources (glycerol, open circles; succinate, closed circles) until complete pho-independent derepression was achieved. The cultures were washed twice with carbon-free TE medium. At time zero, the indicated carbon sources were added to the washed cultures to give final concentrations of $0.4 \%$, except for glucose which was added to a final concentration of $0.2 \%$. At the indicated time points aliquots were assayed for optical density (upper panel), and $\beta$-galactosidase (lower panel) was assayed as described in the legend to Table 1 
Table 2. Effect of different carbon sources on pho-independent $\mathrm{P}_{\text {ugp }}$ directed $\beta$-galactosidase synthesis ${ }^{\text {a }}$

\begin{tabular}{llll}
\hline Carbon source & $\begin{array}{l}\text { Concen- } \\
\text { tration } \\
(\%)\end{array}$ & $\begin{array}{l}\text { cAMP } \\
(\mathrm{mM})\end{array}$ & $\begin{array}{l}\beta \text {-Galactosidase } \\
\text { (units/mg) }\end{array}$ \\
\hline Succinate & 0.4 & 0 & 103682 \\
Glycerol & 0.4 & 0 & 93673 \\
Glucose & 0.2 & 0 & 64738 \\
Glucose & 2.0 & 0 & 5945 \\
Glucose & 2.0 & 5 & 49579 \\
\hline
\end{tabular}

a Strain DL291 harboring pPZ3 [ $\Phi\left(\mathrm{P}_{\text {ugp }}\right.$-lacZ $\left.)\right]$ was grown in TGE medium overnight $(12 \mathrm{~h})$ and $\beta$-galactosidase was assayed as described in Table 1

${ }^{b}$ cAMP was added during late $\log$ phase $\left(\mathrm{A}_{600}=0.8\right)$

Table 3. $\mathrm{P}_{u g p}$-directed catechol 2,3-dioxygenase expression in $\operatorname{crp} p^{+}$ $c y a^{+}$and $c r p c y a$ strains $^{2}$

\begin{tabular}{llrl}
\hline Strain & Genotype & Excess $\mathrm{P}_{\mathrm{i}}$ & Limiting $\mathrm{P}_{\mathrm{i}}$ \\
\hline CA8001 $^{\mathrm{b}}$ & crp $^{+} c y a^{+}$ & 2084 & 45047 \\
CA8306 $^{\mathrm{b}}$ & $\Delta c y a-854$ & 121 & 35318 \\
JK $7^{\mathrm{b}}$ & $\Delta c r p-B S 990$ & 56 & 34308 \\
CA8439 $^{\mathrm{b}}$ & $\Delta c r p-39 \Delta c y a-854$ & 65 & 33495 \\
\hline
\end{tabular}

a Strains harboring plasmid pPX3 were grown in TGE or TGL medium supplemented with $0.2 \%$ glucose and treated as described in Table 1. For strains harboring pPX3,10 $\mathrm{mM} \mathrm{Fe}^{3+}$ was required in growth media due to the high levels of XylE expression. Six hours after dilution into the indicated media, cells were suspended in $50 \mathrm{mM} \mathrm{KPO}_{4}$ buffer (pH 7.5) containing $10 \%$ acetone (acetone assay buffer) and lysed by adding $10 \mu 1$ of toluene plus $20 \mu \mathrm{l}$ of $50 \mathrm{mM}$ TRIS-HCl (pH 8.0), $100 \mathrm{mM}$ EDTA, $100 \mathrm{mM}$ DTT. The cell suspension was kept at $30^{\circ} \mathrm{C}$ for $30 \mathrm{~min}$ and then placed on ice. The assay mixture for XylE was composed of $1 \mathrm{ml}$ of acetone assay buffer, $20 \mu \mathrm{l}$ of $0.5 \mathrm{mM}$ catechol and $20 \mu 1$ of lysed cells. The change in absorbance at $375 \mathrm{~nm}$ was recorded at room temperature. A molar extinction coefficient of $\varepsilon_{375}=4.4 \times 10^{4}$ was used for calculating the specific activity. Specific activities are expressed in nmol of product liberated per minute per mg protein

${ }^{b}$ Strains CA8001, CA8306 and CA8439 were obtained from $\mathbf{J}$. Beckwith. Strain JK 7 was obtained from S. Adhya

pattern of the response of $u g p$ expression to different carbon sources is reminiscent of catabolite-responsive enzyme synthesis, suggesting that the carbon-starvation induction of $u g p$ may be directly or indirectly correlated with catabolite repression.

To further examine the possible involvement of the cAMP-CRP (cAMP receptor protein) control system in carbon-starvation induction, pPX3 was transformed into crp (JK7), cya (CA8306), and cya crp (CA8439) mutant strains and into a wild-type strain (CA8001), and levels of $u g p$ expression were measured. The results shown in Table 3 indicate that the $\mathrm{P}_{u g p}$-directed XylE synthesis was highly repressed in crp or cya mutants when compared to wild-type strain CA8001. These results are in agreement with the results described by Kasahara et al. (1991).

In summary, the results obtained in the present study are in agreement with previous reports that the ugp operon of $E$. coli is induced by both phosphate- and carbon- starvation (Wanner and McSharry 1982; Kasahara et al. 1991), although phosphate-starvation control is the major regulatory mechanism. The reasons for having a dual regulation of $u g p$ expression are not clearly understood. Previous studies have shown that G3P transported via Ugp can only serve as sole source of $P_{i}$ but not carbon, contrary to the conclusion reported by Kasahara et al. (1991). The reason for this so-called "Ugp paradox" is unknown, but it may be the result of a $P_{i}$ imbalance caused by G3P uptake into the cell (Brzoska et al. 1987). Thus, the ability of the ugp promoter to be induced by phosphate- or carbon-starvation could provide the cell not only with a means to adapt to both stresses, but also with a means to fine tune the balance of carbon and phosphate.

At the present time, the mechanism(s) by which carbon starvation induction of $\mathrm{P}_{u g p}$ is exerted remain(s) to be elucidated. Lack of an apparent cAMP-CRP DNA binding site in the ugp control region (Overduin et al. 1988; Kasahara et al. 1991) indicates that the mechanism(s) that cause(s) carbon-starvation-induced $u g p$ expression may themselves be cAMP-CRP-independent, and that the observed effects may be caused by cross-talk with some unidentified, globally controlled cAMP-CRPdependent system.

Acknowledgments. We gratefully acknowledge the receipt of strains and plasmids from B.L. Wanner, F.C. Neidhardt, and S. Adhya. We thank R. Williamson and T.J. Graddis for several helpful discussions. This work was supported by NIH grant GM 11024.

\section{References}

Argast M, Boos W (1980) Co-regulation in Escherichia coli of a novel transport system for $s n$-glycerol-3-phosphate and outer membrane protein Ic $(e, \mathbb{E})$ with alkaline phosphatase and phosphate-binding protein. J Bacteriol 143:142-150

Argast M, Ludtke D, Silhavy TJ, Boos W (1987) A second transport system for $s n$-glycerol-3-phosphate in Escherichia coli. J Bacteriol 136:1070-1083

Brickman E, Beckwith J (1975) Analysis of the regulation of Escherichia coli alkaline phosphatase synthesis using deletion and $\Phi 80$ transducing phages. J Mol Biol 96:307-316

Brzoska P, Boos W (1988) Characteristics of a ugp-encoded and phoB-dependent glycerophosphoryl diester phosphodieterase which is physically dependent on the Ugp transport system of Escherichia coli. J Bacteriol 170:4125-4135

Brzoska P, Schweizer H, Argast M, Boos W (1987) Ugp-dependent transport system for sn-glycerol-3-phosphate of Escherichia coli. In: Torriani-Gorini A, Rothman FG, Silver S, Wright A, Yagil E (eds) Phosphate metabolism and cellular regulation in microorganisms. American Society for Microbiology, Washington, DC, pp 170-177

Echols H, Garen A, Garen S, Torriani A (1961) Genetic control of repression of alkaline phosphatase in $E$. coli. J Mol Biol $3: 425-438$

Ehrmann M, Boos W, Ormseth E, Schweizer H, Larson TJ (1987) Divergent transcription of the $s n$-glycerol-3-phosphate active transport $(g l p T)$ and anaerobic $s n$-glycerol-3-phosphate dehydrogenase $(g l p A g l p C g l p B)$ genes of Escherichia coli K-12. J Bacteriol 169:526-532

Inouye S, Nakazawa A, Nakazawa T (1981 a) Molecular cloning of TOL genes $x y l B$ and $x y l E$ in Escherichia coli. J Bacteriol 145:1137-1143

Inouye H, Michaelis S, Wright A, Beckwith J (1981 b) Cloning 
and restriction mapping of the alkaline phosphatase structural gene (phoA) of Escherichia coli and generation of deletion mutants in vitro. J Bacteriol 146:668-675

Kasahara M, Makino K, Amemura M, Nakata A, Shinagawa H (1991) Dual regulation of the ugp operon by phosphate and carbon starvation at two interspaced promoters. J Bacteriol $173: 549-558$

Lin ECC (1976) Glycerol dissimilation and its regulation in bacteria. Annu Rev Microbiol 30:535-578

Ludtke D, Larson TJ, Beck C, Boos W (1982) Only one gene is required for the $g l p T$-dependent transport of $s n$-glycerol-3phosphate in Escherichia coli. Mol Gen Genet 186:540-547

Miller JH (1972) Experiments in molecular genetics. Cold Spring Harbor Laboratory, Cold Spring Harbor, New York

Overduin P, Boos W, Tommassen J (1988) Nucleotide sequence of the ugp genes of Escherichia coli $\mathrm{K}-12$ : homology to the maltose system. Mol Microbiol 2:767-775
Schweizer H, Boos W (1984) Characterization of the ugp region containing the genes for the phoB-dependent sn-glycerol-3phosphate transport system of Escherichia coli. Mol Gen Genet 197:161-168

Schweizer H, Boos W (1985) Regulation of ugp, the sn-glycerol-3phosphate transport system of Escherichia coli $\mathrm{K}-12$ that is part of the pho regulon. J Bacteriol 163:392-394

Su TZ, Schweizer H, Oxender DL (1990) A novel phosphate-controlled expression vector in Escherichia coli. Gene 90:129-133

Wanner BL, McSharry R (1982) Phosphate-controlled gene expression in Escherichia coli $\mathrm{K} 12$ using MudI-directed lacZ fusion. J Mol Biol 158:347-363

Communicated by J.W. Lengeler 